Bull. Fac.Agric.,Cairo Univ., 64: 67 -77 (2013).

\title{
IMPROVED PRODUCTIVITY OF GERMAN CHAMOMILE BY FOLIAR APPLICATION OF COMPLETE FERTILIZER AND SALICYLIC ACID
}

(Received: 8.12.2012)

\author{
By \\ H.A. El-Shamy and A.S.H.Gendy \\ Horticultural Department, Faculty of Agriculture, Zagazig University, Egypt
}

\begin{abstract}
Different concentrations $(0,2$ and $4 \mathrm{~g} / \mathrm{l})$ of complete fertilizer (Kristalon), salicylic acid (SA) $(0,50$, 100 and $200 \mathrm{ppm}$ ) and their interactions were foliar applied to German chamomile (Matricaria chamomilla L.) to assess their effects on growth and productivity. Obtained results demonstrated that there is linear relationship between increase in Kristalon or SA concentration and increase in most recorded parameters. The maximum values of plant growth characters (plant height and fresh and dry weights of plant), yield components (fresh and dry weights of flowers/plant, dry weight of flowers/feddan, essential oil \%, essential oil yield/plant and feddan) and chemical constituents (total chlorophylls and the total percentages of carbohydrate, nitrogen, crude protein, phosphorus and potassium) were achieved by spraying the plants with the highest concentrations of Kristalon and SA.
\end{abstract}

Key words: foliar application, german chamomile, kristalon, salicylic acid.

\section{INTRODUCTION}

German chamomile (Matricaria chamomilla L.) belongs to family Asteraceae is one of the most widely used medicinal plants in the world (Salamon, 2007). The flowers are used as herbal tea for cough and cold and for promoting the flow of gastric secretion and bile. It is also used in inflammatory diseases of the gastrointestinal tract and gastrointestinal spasm. Externally, it is used for skin, mucous membrane and ano-genital inflammation and bacterial skin diseases (Khare, 2007).

Plants normally take up nutrients from the soil through their roots although nutrients can be supplied to the plants as fertilizers by foliar sprays. Foliar feeding is a relatively new and controversial technique of feeding plants by applying liquid fertilizers directly to their leaves (Bernal et al., 2007 and Baloch et al., 2008).

The role of macro and micronutrients is crucial in crop nutrition and thus important for achieving higher yields. The application of macro and micronutrient fertilizers in the cultivation zone may not be meeting the crop requirements for root growth and nutrient use. The alternative approach is to apply these micronutrients as foliar sprays. Foliar application can guarantee the availability of nutrients to crops for obtaining high yields(Arif $e t$ al., 2006).
Rapid uptake of nutrients applied to crop foliage ensures a fast response within the plant as micronutrients directly enter the metabolic processes. Micronutrients are completely available to the plant and thus particularly effective because they are not fixed or diluted in large volumes of soil (Baloch et al., 2008).

Salicylic acid (SA) is important phytohormone that plays a role in response to biotic stresses and pathogenesis. Apart from this role, recent studies have demonstrated that SA also participates in the signaling of abiotic stress responses. The appropriate application of SA could provide protection against several types of environmental stresses (Hara et al., 2011). It has important role in the regulation of plant growth and development (Szepesi et al., 2008). It has been proven to be effective in enhancing plant growth (Shakirova $e t$ al., 2003; Gharib, 2006; Gunes et al., 2007 and Elwan and El-Hamahmy, 2009) and volatile oil production (Gharib, 2006).

SA has a direct physiological effect through the alteration of antioxidant enzyme activities. Certain enzymes were activated by SA treatment, while others like catalase, were inhibited. Catalase seems to be a key enzyme in SA-induced stress tolerance, as it was inhibited by binding in several plant species (Chen et al., 1993; Conrath et al., 1995). 
Although there are a few hydroponical experiments conducted to study the effect of feeding German chamomile roots with SA on the biosynthesis of coumarin (Pastírová et al., 2004) or phenolic (Kováčik et al., 2009), no available literature about the effect of SA on German chamomile plant growth and productivity.

Up to now there exist only a few publications on the effect of foliar spray with fertilizers and SA and their interaction effect on plant growth and development but no information has been reported concerning the effect of these treatments on German chamomile plant growth and production. Therefore, the present paper was designed to evaluate the influence of foliar application with different concentrations of complete fertilizer (Kristalon), salicylic acid and their interactions on German chamomile plant growth and productivity.

\section{MATERIALS AND METHODS}

This study was performed at a private farm at Salhia, Sharkia Governorate, Egypt, during the two consecutive seasons of 2009/2010 and 2010/2011. The aim was to investigate growth, flowering and chemical composition of German chamomile (Matricaria chamomilla L.) as influenced by a complete fertilizer (Kristalon) and salicylic acid. Physical and chemical properties of the experimental farm soil are presented in Table (1).

Seeds of German chamomile (Matricaria chamomilla L.) were obtained from the Research Centre of Medicinal and Aromatic Plants, Dokky, Giza and were sown in the nursery on the $8^{\text {th }}$ of October during both seasons (2009 and 2010). Uniform seedlings (about $10 \mathrm{~cm}$ length) were transplanted after 40 days from sowing. Drip irrigation system was used. Chicken manure was added during soil preparation at the rate of 20 $\mathrm{m}^{3} /$ feddan. The experimental plot area was $2 \times 3$ meter included five rows; each row was $60 \mathrm{~cm}$ apart. The distance between plants was $40 \mathrm{~cm}$. Each plot contained 25 plants.

The statistical layout of this experiment was split plot design with three replicates. Each replicate was represented by one plot. Levels of Kristalon $(0,2$ and $4 \mathrm{~g} / \mathrm{l})$ were arranged in the main plots while salicylic acid concentrations $(0$, 50, 100 and $200 \mathrm{ppm}$ ) were assigned at sub-plots. The total experimental treatments were twelve. Kristalon was obtained from Hydro Agric. Trade Egypt Co. The chemical composition of Kristalon was as follows:

Macro elements: nitrogen (N) $19 \%$, phosphorus $\left(\mathrm{P}_{2} \mathrm{O}_{5}\right) 19 \%$, Potassium $\left(\mathrm{K}_{2} \mathrm{O}\right) 19 \%$ and magnesium $(\mathrm{Mg}) 1.5 \%$.

Microelements: boron (B) $0.025 \%$, manganese (Mn) $0.01 \%$, cupper $(\mathrm{Cu}) 0.01 \%$ and molybdenum (Mo) $0.001 \%$.

The plants were sprayed with aqueous solution of complete fertilizer (Kristalon) and salicylic acid three times, the first one at 21 days after transplanting, while the second and the third ones were applied at 15 days intervals after the first one in both seasons. All plants received normal agricultural practices when they needed.

Table (1): Physical and chemical properties of the experimental farm soil.

\begin{tabular}{|c|c|c|c|}
\hline Sand \% & 86.50 & $\mathrm{Cl}^{-} \%$ & 2.00 \\
\hline Slit \% & 8.35 & $\mathrm{SO}_{4}{ }^{-\%} \%$ & 4.86 \\
\hline Clay \% & 5.15 & $\mathrm{CaCO3} \%$ & 3.10 \\
\hline Soil texture & Sandy & \multicolumn{2}{|c|}{ Macro elements (ppm) } \\
\hline Organic matter \% & 0.42 & Nitrogen & 10.15 \\
\hline pH & 7.5 & Phosphorus & 7.23 \\
\hline EC (mmohs/cm) & 0.42 & Potassium & 5.40 \\
\hline \multicolumn{2}{|c|}{ Soluble ions cmol kg ${ }^{-1}$} & \multicolumn{2}{|c|}{ Micro elements (ppm) } \\
\hline $\mathrm{Ca}^{++}$ & 0.014 & $\mathbf{F e}$ & 10.6 \\
\hline $\mathbf{M g}^{++}$ & 0.011 & $\mathbf{C u}$ & 0.85 \\
\hline $\mathrm{Na}^{+}$ & 0.096 & $\mathbf{Z n}$ & 1.25 \\
\hline $\mathrm{HCO}_{3} \%$ & 2.50 & Mn & 0.80 \\
\hline
\end{tabular}

Plants from the middle lines of drip irrigation at full flowering stage were used to record the vegetative growth parameters as follows; plant height $(\mathrm{cm})$, number of branches per plant and fresh and dry weight of the plant (g).

Six successive harvests of chamomile flower heads were taken at intervals of about seven days and the following data were recorded; Fresh weight of flowers per plant (g), dry weight of flowers per plant $(\mathrm{g})$ and dry weight of flowers per feddan $(\mathrm{kg})$. The flowers were air dried in shade.

Essential oil percentage was determined in dried flower samples according to Anonymous (1996). Essential oil yield per plant (g) was calculated by multiplying the essential oil percentage by flower dry weight of the plant. Essential oil yield per faddan was calculated by multiplying the essential oil yield of the plant by the number of plants per feddan.

Total chlorophylls $(\mathrm{a}+\mathrm{b})$ content $(\mathrm{mg} / \mathrm{g})$ was determined in fresh leaves according to (Gross, 1991). Samples from dry herb of each treatment were used to determine the following chemical constituents: total carbohydrate percentage was determined according to Herbert et al. (1971) and then total carbohydrate content per plant was calculated, total nitrogen percentage was 
determined as described by Naguib (1969). Total crude protein percentage was calculated, total phosphorus percentage was determined according to the methods adapted by Hucker and Catroux (1980) and potassium percentage was determined according to the method described by Brown and Lilleland (1964).

The recoded data were statistically analyzed, and the means were compared using Duncan multiple range test according to (Gomez and Gomez, 1984).

\section{RESULTS AND DISCUSSION \\ 3.1. Vegetative growth parameters}

From the data presented in Table (2) it was observed that, both plant height and the number of branches/plant were significantly enhanced by increasing Kristalon rate. The highest means of plant height (88.21 and $83.34 \mathrm{~cm})$ and the number of branches/plant (35.33 and 32.83) were recorded with the highest rate of Kristalon $(4 \mathrm{~g} / \mathrm{l})$ during both seasons, respectively. Plant height and the number of branches/plant were gradually increased with increasing the applied concentration of SA up to $50 \mathrm{ppm}$ while higher concentration $(100 \mathrm{ppm})$ resulted in lower values. The exception was that there was no significant difference in the number of branches/plant between 50 and 100 ppm SA during the second season.

The interaction between different concentrations of both Kristalon and SA showed that the highest values of plant height and the number of branches/plant were recorded when the plants were sprayed with the highest Kristalon concentration combined with 50 or 100 ppm SA.

Concerning the fresh and dry weights of the plants (Table 3), it is clear that increasing the applied concentration of Kristalon or SA within the examined range significantly enhanced fresh and dry weights of the plants. The highest significant values of fresh and dry weights (192.99 -196.15 and 42.49 - $45.21 \mathrm{~g}$ ) were obtained by treating the plants with the highest rates of Kristalon (4 g/l) and SA (100 ppm) during both seasons, respectively.

The present results suggest that there is linear relationship between increase in foliar fertilizer rate and increase in plant growth parameters. This effect was also reported on other plants such as Ruta graveolens (Naguib et al., 2005 and ElSherbeny et al., 2008), Capsicum annuum (Baloch et al., 2008) and Iris tingitana (Taha, 2012). This might be attributed to the fact that foliar nutrition treatments can serve as an efficient method of improving the level of mineral nutrient utilization and, in consequence, plant fitness (Elmer et al., 2007)

The enhancing effect of SA especially at moderate concentration on growth reported here was previously demonstrated by many investigators (Mendoza et al., 2002, Shakirova et al., 2003, Gharib 2006, Gunes et al,. 2007 and Elwan and El-Hamahmy, 2009). Plant growth stimulation as a response of some SA doses can be attributed to a change in the hormonal status (Shakirova et al., 2003) or for the improvement of photosynthesis, transpiration and stomatal conductance (Stevens et al., 2006). Other reason is that SA had a stimulative effect on the size of the root which reflected on plant growth (GutierrezCoronado et al., 1998 and Sandoval-Yepiz, 2004). It is clear that SA importantly contributes to growth and development regulation, although the biochemical mechanisms that mediate most of these responses remain largely unknown (Vicente and Plasencia, 2011).

\subsection{Yield components}

There was a significant linear relationship between the increase in Kristalon or SA concentrations and the increase in fresh and dry weights of flowers/plant (Table 4). Spraying plants with the highest concentration of Kristalon or SA gave the highest flower fresh and dry weights per plant.

Generally, the highest values of fresh and dry weights of flowers/plant were resulted from the combination between the highest concentrations of Kristalon $(4 \mathrm{~g} / \mathrm{l})$ and SA (100 ppm) which produced $144.83-136.72 \mathrm{~g}$ and $28.83-26.93 \mathrm{~g}$ during both seasons, respectively. On the other hand, the lowest fresh and dry weights of flowers/plant were obtained from plants which were not sprayed with either Kristalon or SA (control).

Dry flowers yield /feddan followed the similar trend of dry weight of flower per plant since the maximum yield was recorded by treating the plants with either Kristalon or SA each alone (Table 5). The highest dry flowers yields (504.53 and $471.28 \mathrm{~kg} / \mathrm{feddan}$ ) were gained when the plants were sprayed with the highest concentration of both Kristalon and SA during both seasons, respectively. There was no significant difference between moderate $(50 \mathrm{ppm})$ and high $(100 \mathrm{ppm})$ concentrations of SA in the first season.

As shown in Table (5), it could be concluded that as the concentration of Kristalon increased, the volatile oil percentage increased throughout the examined range. The highest concentration of 
Table (2): Effect of complete fertilizer (Kristalon) and salicylic acid concentrations on plant height and the number of branches per plant of German chamomile (Matricaria chamomilla $\mathbf{L}$.) during both seasons.

\begin{tabular}{|c|c|c|c|c|c|c|c|c|c|c|}
\hline \multirow{4}{*}{$\begin{array}{l}\text { Kristalon } \\
\text { Conc. (g/l) } \\
\end{array}$} & \multicolumn{10}{|c|}{ Salicylic acid conc. (ppm) } \\
\hline & 0.0 & 25 & 50 & 100 & Mean & 0.0 & 25 & 50 & 100 & Mean \\
\hline & \multicolumn{5}{|c|}{ First season } & \multicolumn{5}{|c|}{ Second season } \\
\hline & \multicolumn{10}{|c|}{ Plant height (cm) } \\
\hline 0.0 & $71.23 \mathrm{a}$ & $77.00 \mathrm{~b}$ & $84.06 \mathrm{e}$ & $82.10 \mathrm{~d}$ & $78.60 \mathrm{~A}$ & $71.26 \mathrm{a}$ & $74.50 \mathrm{c}$ & $79.73 \mathrm{e}$ & $78.60 \mathrm{~d}$ & $76.02 \mathrm{~A}$ \\
\hline 2.0 & $77.06 \mathrm{~b}$ & $80.30 \mathrm{c}$ & $88.00 \mathrm{~g}$ & $83.88 \mathrm{e}$ & $82.31 \mathrm{~B}$ & $73.10 \mathrm{~b}$ & $78.36 \mathrm{~d}$ & $82.70 \mathrm{~g}$ & $81.26 \mathrm{f}$ & $78.85 \mathrm{~B}$ \\
\hline 4.0 & $80.94 \mathrm{c}$ & $85.51 \mathrm{f}$ & $93.96 \mathrm{~h}$ & $92.43 \mathrm{~h}$ & $88.21 \mathrm{C}$ & $77.56 \mathrm{~d}$ & $81.33 \mathrm{f}$ & $85.23 \mathrm{~h}$ & $89.23 \mathrm{i}$ & $83.34 \mathrm{C}$ \\
\hline \multirow[t]{2}{*}{ Mean } & $76.41 \mathrm{~A}$ & $80.93 \mathrm{~B}$ & $88.67 \mathrm{D}$ & $86.13 \mathrm{C}$ & & $73.97 \mathrm{~A}$ & $78.06 \mathrm{~B}$ & $83.88 \mathrm{D}$ & $81.70 \mathrm{C}$ & \\
\hline & \multicolumn{10}{|c|}{$\begin{array}{l}\text { Number of branches per plant } \\
\end{array}$} \\
\hline $\mathbf{0 . 0}$ & $29.00 \mathrm{a}$ & $30.00 \mathrm{ab}$ & $33.00 \mathrm{~cd}$ & $30.66 \mathrm{~b}$ & $30.66 \mathrm{~A}$ & $27.00 \mathrm{a}$ & $29.00 \mathrm{c}$ & $31.00 \mathrm{de}$ & $30.66 \mathrm{~d}$ & $29.41 \mathrm{~A}$ \\
\hline 2.0 & $31.00 \mathrm{bc}$ & $32.00 \mathrm{c}$ & $35.00 \mathrm{~d}$ & $34.00 \mathrm{~d}$ & $33.00 \mathrm{~B}$ & $28.00 \mathrm{~b}$ & $30.00 \mathrm{~cd}$ & $32.33 \mathrm{e}$ & $31.33 \mathrm{de}$ & $30.41 \mathrm{~B}$ \\
\hline 4.0 & $32.00 \mathrm{c}$ & $35.00 \mathrm{~d}$ & $37.33 \mathrm{e}$ & $37.00 \mathrm{e}$ & $35.33 \mathrm{C}$ & $30.00 \mathrm{~cd}$ & $32.00 \mathrm{e}$ & $35.33 \mathrm{~g}$ & $34.00 \mathrm{f}$ & $32.83 \mathrm{C}$ \\
\hline Mean & $30.66 \mathrm{~A}$ & $32.33 \mathrm{~B}$ & $35.11 \mathrm{D}$ & $33.88 \mathrm{C}$ & & $28.33 \mathrm{~A}$ & $30.33 \mathrm{~B}$ & $32.88 \mathrm{D}$ & $32.00 \mathrm{D}$ & \\
\hline
\end{tabular}

Table (3): Effect of complete fertilizer (Kristalon) and salicylic acid concentrations on the fresh and dry weights (g) of German chamomile (Matricaria chamomilla L.) plant during both seasons.

\begin{tabular}{|c|c|c|c|c|c|c|c|c|c|c|}
\hline \multirow{2}{*}{$\begin{array}{l}\text { Kristalon } \\
\text { Conc. (g/l) }\end{array}$} & \multicolumn{10}{|c|}{ Salicylic acid conc. (ppm) } \\
\hline & $\mathbf{0 . 0}$ & 25 & 50 & 100 & Mean & 0.0 & 25 & 50 & 100 & Mean \\
\hline & \multicolumn{5}{|c|}{ First season } & \multicolumn{5}{|c|}{ Second season } \\
\hline & \multicolumn{10}{|c|}{ Fresh weight of plant (g) } \\
\hline $\mathbf{0 . 0}$ & $132.20 \mathrm{a}$ & $158.28 \mathrm{~b}$ & $163.31 \mathrm{c}$ & $170.62 \mathrm{~d}$ & $156.10 \mathrm{~A}$ & $136.15 \mathrm{a}$ & $162.44 \mathrm{~b}$ & $166.33 \mathrm{c}$ & $173.92 \mathrm{de}$ & $159.71 \mathrm{~A}$ \\
\hline 2.0 & $168.40 \mathrm{~d}$ & $172.55 \mathrm{e}$ & $178.00 \mathrm{~g}$ & $181.52 \mathrm{~h}$ & $175.11 \mathrm{~B}$ & $171.55 \mathrm{~d}$ & $175.44 \mathrm{e}$ & $181.03 \mathrm{~g}$ & $184.92 \mathrm{~h}$ & $178.23 \mathrm{~B}$ \\
\hline 4.0 & $175.58 \mathrm{f}$ & $182.82 \mathrm{~h}$ & $186.71 \mathrm{i}$ & $192.99 \mathrm{j}$ & $184.53 \mathrm{C}$ & $178.83 \mathrm{f}$ & $187.50 \mathrm{i}$ & $190.85 \mathrm{j}$ & $196.15 \mathrm{k}$ & $188.33 \mathrm{C}$ \\
\hline \multirow[t]{2}{*}{ Mean } & $158.72 \mathrm{~A}$ & $171.22 \mathrm{~B}$ & $176.01 \mathrm{C}$ & $181.71 \mathrm{D}$ & & $162.17 \mathrm{~A}$ & $175.12 \mathrm{~B}$ & $179.40 \mathrm{C}$ & $184.99 \mathrm{D}$ & \\
\hline & \multicolumn{10}{|c|}{ Dry weight of plant (g) } \\
\hline 0.0 & $28.36 \mathrm{a}$ & $30.57 \mathrm{~b}$ & $32.60 \mathrm{bc}$ & $34.61 \mathrm{~cd}$ & $31.53 \mathrm{~A}$ & $30.35 \mathrm{a}$ & $33.31 \mathrm{~b}$ & $35.23 \mathrm{c}$ & $37.29 \mathrm{~d}$ & $34.04 \mathrm{~A}$ \\
\hline 2.0 & $30.56 \mathrm{~b}$ & $33.55 \mathrm{c}$ & $35.51 \mathrm{~cd}$ & $36.48 \mathrm{de}$ & $34.02 \mathrm{~B}$ & $33.30 \mathrm{~b}$ & $36.18 \mathrm{~cd}$ & $37.22 \mathrm{~d}$ & $38.76 \mathrm{e}$ & $36.36 \mathrm{~B}$ \\
\hline 4.0 & $33.37 \mathrm{c}$ & $36.10 \mathrm{~d}$ & $38.48 \mathrm{e}$ & $42.49 \mathrm{f}$ & $37.61 \mathrm{C}$ & $35.78 \mathrm{c}$ & $38.56 \mathrm{de}$ & $40.44 \mathrm{f}$ & $45.21 \mathrm{~g}$ & $40.00 \mathrm{C}$ \\
\hline Mean & $30.76 \mathrm{~A}$ & $33.41 \mathrm{~B}$ & $35.53 \mathrm{C}$ & $37.86 \mathrm{D}$ & & $33.14 \mathrm{~A}$ & $36.02 \mathrm{~B}$ & $37.63 \mathrm{C}$ & $40.42 \mathrm{D}$ & \\
\hline
\end{tabular}


Table (4): Effect of complete fertilizer (Kristalon) and salicylic acid concentrations on the fresh and dry weights (g) of German chamomile (Matricaria chamomilla L.) plant flowers during both seasons.

\begin{tabular}{|c|c|c|c|c|c|c|c|c|c|c|}
\hline \multirow{4}{*}{$\begin{array}{l}\text { Kristalon } \\
\text { Conc. (g/l) }\end{array}$} & \multicolumn{10}{|c|}{ Salicylic acid conc. (ppm) } \\
\hline & 0.0 & 25 & 50 & 100 & Mean & 0.0 & 25 & 50 & 100 & Mean \\
\hline & \multicolumn{5}{|c|}{ First season } & \multicolumn{5}{|c|}{ Second season } \\
\hline & \multicolumn{10}{|c|}{ Fresh weight of flowers per plant (g) } \\
\hline 0.0 & $113.33 \mathrm{a}$ & $124.00 \mathrm{~b}$ & $127.50 \mathrm{c}$ & $131.23 \mathrm{e}$ & $124.01 \mathrm{~A}$ & $110.16 \mathrm{a}$ & $121.10 \mathrm{~b}$ & $124.61 \mathrm{c}$ & $127.73 \mathrm{~d}$ & $120.90 \mathrm{~A}$ \\
\hline 2.0 & $125.13 \mathrm{~b}$ & $130.60 \mathrm{de}$ & $134.63 \mathrm{f}$ & $138.20 \mathrm{~g}$ & $132.14 \mathrm{~B}$ & $121.66 \mathrm{~b}$ & $125.93 \mathrm{~cd}$ & $129.40 \mathrm{e}$ & $133.76 \mathrm{f}$ & $127.69 \mathrm{~B}$ \\
\hline 4.0 & $129.46 \mathrm{~d}$ & $133.20 \mathrm{f}$ & $137.23 \mathrm{~g}$ & $144.83 \mathrm{~h}$ & $136.18 \mathrm{C}$ & 126.50 & $130.93 \mathrm{e}$ & $133.73 \mathrm{f}$ & $136.72 \mathrm{~g}$ & $131.97 \mathrm{C}$ \\
\hline \multirow[t]{2}{*}{ Mean } & $122.64 \mathrm{~A}$ & $129.26 \mathrm{~B}$ & $133.12 \mathrm{C}$ & $138.08 \mathrm{D}$ & & $119.44 \mathrm{~A}$ & $125.98 \mathrm{~B}$ & $129.25 \mathrm{C}$ & $132.74 \mathrm{D}$ & \\
\hline & \multicolumn{10}{|c|}{ Dry weight of flowers per plant (g) } \\
\hline $\mathbf{0 . 0}$ & $19.42 \mathrm{a}$ & $21.32 \mathrm{~b}$ & $22.25 \mathrm{bc}$ & $24.64 \mathrm{~cd}$ & $21.91 \mathrm{~A}$ & $17.93 \mathrm{a}$ & $20.39 \mathrm{~b}$ & $21.62 \mathrm{bc}$ & $23.57 \mathrm{de}$ & $20.88 \mathrm{~A}$ \\
\hline 2.0 & $22.26 \mathrm{bc}$ & $23.53 \mathrm{c}$ & $24.62 \mathrm{~cd}$ & $26.83 \mathrm{e}$ & $24.31 \mathrm{~B}$ & $20.80 \mathrm{~b}$ & $23.15 \mathrm{~d}$ & $23.96 \mathrm{de}$ & $24.10 \mathrm{e}$ & $23.00 \mathrm{~B}$ \\
\hline 4.0 & $23.42 \mathrm{c}$ & $24.91 \mathrm{~d}$ & $27.64 \mathrm{ef}$ & $28.83 \mathrm{f}$ & $26.20 \mathrm{C}$ & $21.88 \mathrm{c}$ & $23.93 \mathrm{de}$ & $25.87 \mathrm{f}$ & $26.93 \mathrm{~g}$ & $24.65 \mathrm{C}$ \\
\hline Mean & $21.70 \mathrm{~A}$ & $23.25 \mathrm{~B}$ & $24.84 \mathrm{C}$ & $26.76 \mathrm{D}$ & & $20.20 \mathrm{~A}$ & $22.49 \mathrm{~B}$ & $23.82 \mathrm{C}$ & $24.87 \mathrm{D}$ & \\
\hline
\end{tabular}

Table (5): Effect of complete fertilizer (Kristalon) and salicylic acid concentrations on the dry flowers yield/feddan (kg) and volatile oil percentage of German chamomile (Matricaria chamomilla $\mathbf{L}$.) plant during both seasons.

\begin{tabular}{|c|c|c|c|c|c|c|c|c|c|c|}
\hline \multirow{4}{*}{$\begin{array}{l}\text { Kristalon } \\
\text { Conc. (g/l) }\end{array}$} & \multicolumn{10}{|c|}{ Salicylic acid conc. (ppm) } \\
\hline & $\mathbf{0 . 0}$ & 25 & 50 & 100 & Mean & 0.0 & 25 & 50 & 100 & Mean \\
\hline & \multicolumn{5}{|c|}{ First season } & \multicolumn{5}{|c|}{ Second season } \\
\hline & \multicolumn{10}{|c|}{ Dry flowers yield/feddan (kg) } \\
\hline $\mathbf{0 . 0}$ & $339.85 \mathrm{a}$ & $373.10 \mathrm{~b}$ & $389.38 \mathrm{bc}$ & $431.20 \mathrm{~cd}$ & $383.38 \mathrm{~A}$ & $313.78 \mathrm{a}$ & $356.83 \mathrm{~b}$ & $378.35 \mathrm{c}$ & $412.48 \mathrm{de}$ & $365.36 \mathrm{~A}$ \\
\hline 2.0 & $389.55 \mathrm{bc}$ & $411.78 \mathrm{c}$ & $430.85 \mathrm{~cd}$ & $469.25 \mathrm{e}$ & $425.36 \mathrm{~B}$ & $364.00 \mathrm{~b}$ & $405.13 \mathrm{~d}$ & $419.30 \mathrm{e}$ & $421.75 \mathrm{e}$ & $402.55 \mathrm{~B}$ \\
\hline 4.0 & $409.85 \mathrm{c}$ & $435.93 \mathrm{~d}$ & 483.70 ef & $504.53 \mathrm{f}$ & $458.50 \mathrm{C}$ & $382.90 \mathrm{c}$ & $418.78 \mathrm{e}$ & $452.73 \mathrm{f}$ & $471.28 \mathrm{~g}$ & $431.42 \mathrm{C}$ \\
\hline \multirow[t]{2}{*}{ Mean } & $379.75 \mathrm{~A}$ & $406.94 \mathrm{~B}$ & $434.64 \mathrm{C}$ & $468.33 \mathrm{D}$ & & $353.56 \mathrm{~A}$ & $393.58 \mathrm{~B}$ & $416.79 \mathrm{C}$ & $435.17 \mathrm{D}$ & \\
\hline & \multicolumn{10}{|c|}{ Volatile oil percentage } \\
\hline 0.0 & $0.537 \mathrm{a}$ & $0.560 \mathrm{~b}$ & $0.580 \mathrm{c}$ & $0.583 \mathrm{c}$ & $0.565 \mathrm{~A}$ & $0.503 \mathrm{a}$ & $0.520 \mathrm{~b}$ & $0.540 \mathrm{~cd}$ & $0.540 \mathrm{~cd}$ & $0.526 \mathrm{~A}$ \\
\hline 2.0 & $0.570 \mathrm{bc}$ & $0.580 \mathrm{c}$ & $0.600 \mathrm{~d}$ & $0.600 \mathrm{~d}$ & $0.587 \mathrm{~B}$ & $0.510 \mathrm{ab}$ & $0.530 \mathrm{bc}$ & $0.540 \mathrm{~cd}$ & $0.550 \mathrm{~d}$ & $0.533 \mathrm{~B}$ \\
\hline 4.0 & $0.580 \mathrm{c}$ & $0.603 \mathrm{de}$ & $0.613 \mathrm{e}$ & $0.630 \mathrm{f}$ & $0.607 \mathrm{C}$ & $0.520 \mathrm{~b}$ & $0.540 \mathrm{~cd}$ & $0.560 \mathrm{~d}$ & $0.573 \mathrm{e}$ & $0.548 \mathrm{C}$ \\
\hline Mean & $0.562 \mathrm{~A}$ & $0.581 \mathrm{~B}$ & $0.598 \mathrm{C}$ & $0.604 \mathrm{C}$ & & $0.511 \mathrm{~A}$ & $0.530 \mathrm{~B}$ & $0.547 \mathrm{C}$ & $0.554 \mathrm{C}$ & \\
\hline
\end{tabular}


Kristalon resulted in the maximum volatile oil percentage. Treating plants with SA resulted in enhancing of volatile oil percentage without significant difference between moderate $(50 \mathrm{ppm})$ and high $(100 \mathrm{ppm})$ concentrations. The interaction effect showed that the greatest volatile oil percentages were belonged to the treatment of $4 \mathrm{~g} / \mathrm{l}$ Kristalon combined with 100 ppm SA which produced 0.630 and $0.573 \%$ during both seasons, respectively.

As seen in Table (6), spraying the plants with either Kristalon or SA could enhance volatile oil yield per plant and feddan. The highest concentration of each material gave the highest mean yield per plant and feddan. Comparing the interaction between different concentrations of Kristalon and SA showed that treating the plants with the highest concentration of Kristalon and SA proved to be the best treatment for enhancing the volatile oil yield either per plant $(0.182$ and 0.154 $\mathrm{ml})$ or feddan $(3.19$ and $2.70 \mathrm{~L})$ during both seasons, respectively.

The positive effect of spraying plants with fertilizers on yield has been reported in the present study and previously demonstrated by some investigators (Naguib et al., 2005, Baloch et al., 2008 El-Sherbeny et al., 2008 and Taha, 2012). The increment in essential oil yield per plant and feddan as a result of treating plants with Kristalon, could be interpreted as a reflection of raising flower dry weight. On the other hand, the essential oil biosynthesis in the plant is the result of integration of several metabolic pathways which require linking of several steps such as continuous production of precursors, their transport and translocation to the active site of synthesis, and finally upon normal functioning of associated metabolic pathways such as carbon fixation, respiration, and isoprenoid pathway. This also may be due to the effect on enzyme activity which improved the essential oil metabolism (Naguib et al., 2005).

The advantage of treating plants with SA for enhancing plant yield has been reported here and previously demonstrated by other researchers (Gharib, 2006; Gunes et al., 2007 and Elwan and El-Hamahmy, 2009). This beneficial effect of SA on yield may be due to the translocation of more photoassimilates toward flowers and essential oil production. Increase in volatile oil percentage and yield with respect to SA addition could be attributed to the fact that SA acts as a powerful inducing signal. SA indeed induces gene expression related to biosynthesis and production of some classes of secondary metabolites in plants
(Taguchi et al., 2001). The sustained level of SA may be a prerequisite for the synthesis of auxin and/or cytokinin (Metwally et al., 2003), yet the influence of SA on essential oil production and secondary metabolism in general, has received little attention. It is well known now that the production of secondary metabolites can be enhanced by the treatment of the undifferentiated cells with elicitors such as salicylic acid.

\subsection{Chemical constituents}

Data in Table (7) indicate that, treating the plants with each compound (Kristalon or SA) promoted the formation of chlorophyll. The highest means of total chlorophyll content were recorded when the plants were sprayed with the highest concentration of each compound. The highest chlorophyll contents (4.96 and $5.21 \mathrm{mg} / \mathrm{g}$ ) were observed with the treatment of $4 \mathrm{~g} / \mathrm{l} \mathrm{Kristalon} \mathrm{combined} \mathrm{with} 100$ ppm SA during both seasons, respectively.

As shown in Table (7), the average of total carbohydrate percentage was increased by increasing either Kristalon or SA concentration. There was no significant difference between the control and low Kristalon concentration $(2 \mathrm{~g} / \mathrm{l})$ treatments during the second season.

The interaction between Kristalon and SA concentrations show that all the applied treatments resulted in significant increase in total carbohydrate percentage compared to the control treatment. The highest values belonged to the interaction treatments between high or moderate concentrations of SA (50 and $100 \mathrm{ppm}$ ) and different concentrations of Kristalon.

Tables (8 \&9) show the effect of different concentrations of Kristalon and SA on nitrogen, crude protein, phosphorus and potassium percentages. From these data it could be concluded that the highest concentration of each compound gave the highest significant average values. Treating the plants with the highest rate of Kristalon $(4 \mathrm{~g} / \mathrm{l})$ and moderate $(50 \mathrm{ppm})$ or high $(100 \mathrm{ppm})$ concentrations of SA gave the highest values of nitrogen and crude protein percentages. Spraying the plants with the highest concentration of both compounds proved to be the best treatment for enhancing phosphorus and potassium percentages in the plants.

The primitive effect of foliar fertilization on plant nutrients content ( Naguib et al., 2005 and Taha, 2012), carbohydrate percentage ( Khalil et al., 2001, Kandeel, 2002 and Naguib et al., 2005) and chlorophyll content (Aziz, 2004 and Naguib et al., 2005) was previously reported and demonstrated in the current research. This may be due to the effect of foliar nutrition as an efficient method for 
Table (6): Effect of complete fertilizer (Kristalon) and salicylic acid concentrations on volatile oil yield per plant (ml) and feddan (L) of German chamomile (Matricaria chamomilla L.) plant during both seasons.

\begin{tabular}{|c|c|c|c|c|c|c|c|c|c|c|}
\hline \multirow{4}{*}{$\begin{array}{l}\text { Kristalon } \\
\text { Conc. (g/l) } \\
\end{array}$} & \multicolumn{10}{|c|}{ Salicylic acid conc. (ppm) } \\
\hline & 0.0 & 25 & 50 & 100 & Mean & $\mathbf{0 . 0}$ & 25 & $\mathbf{5 0}$ & 100 & Mean \\
\hline & \multicolumn{5}{|c|}{ First season } & \multicolumn{5}{|c|}{ Second season } \\
\hline & \multicolumn{10}{|c|}{ Volatile oil yield/ plant $(\mathrm{ml})$} \\
\hline 0.0 & $0.104 \mathrm{a}$ & $0.119 \mathrm{~b}$ & $0.129 \mathrm{~cd}$ & $0.144 \mathrm{e}$ & $0.124 \mathrm{~A}$ & $0.090 \mathrm{a}$ & $0.106 \mathrm{~b}$ & $0.117 \mathrm{c}$ & $0.127 \mathrm{de}$ & $0.110 \mathrm{~A}$ \\
\hline 2.0 & $0.127 \mathrm{c}$ & $0.136 \mathrm{~d}$ & $0.148 \mathrm{e}$ & $0.161 \mathrm{f}$ & $0.143 \mathrm{~B}$ & $0.106 \mathrm{~b}$ & $0.123 \mathrm{~d}$ & $0.129 \mathrm{e}$ & $0.133 \mathrm{e}$ & $0.123 \mathrm{~B}$ \\
\hline 4.0 & $0.136 \mathrm{~d}$ & $0.150 \mathrm{e}$ & $0.169 \mathrm{~g}$ & $0.182 \mathrm{~h}$ & $0.159 \mathrm{C}$ & $0.114 \mathrm{c}$ & $0.129 \mathrm{e}$ & $0.145 \mathrm{f}$ & $0.154 \mathrm{~g}$ & $0.136 \mathrm{C}$ \\
\hline \multirow[t]{2}{*}{ Mean } & $0.122 \mathrm{~A}$ & $0.135 \mathrm{~B}$ & $0.148 \mathrm{C}$ & $0.162 \mathrm{D}$ & & $0.103 \mathrm{~A}$ & $0.119 \mathrm{~B}$ & $0.130 \mathrm{C}$ & $0.138 \mathrm{D}$ & \\
\hline & \multicolumn{10}{|c|}{$\begin{array}{c}\text { Volatile oil yield /faddan }(\mathrm{L}) \\
\end{array}$} \\
\hline $\mathbf{0 . 0}$ & $1.82 \mathrm{a}$ & $2.08 \mathrm{~b}$ & $2.26 \mathrm{c}$ & $2.52 \mathrm{~d}$ & $2.17 \mathrm{~A}$ & $1.58 \mathrm{a}$ & $1.86 \mathrm{~b}$ & $2.05 \mathrm{c}$ & $2.22 \mathrm{de}$ & $1.93 \mathrm{~A}$ \\
\hline 2.0 & $2.22 \mathrm{bc}$ & $2.38 \mathrm{~cd}$ & $2.59 \mathrm{~d}$ & $2.82 \mathrm{e}$ & $2.50 \mathrm{~B}$ & $1.86 \mathrm{~b}$ & $2.15 \mathrm{~d}$ & $2.26 \mathrm{e}$ & $2.33 \mathrm{e}$ & $2.15 \mathrm{~B}$ \\
\hline 4.0 & $2.38 \mathrm{c}$ & $2.63 \mathrm{~d}$ & $2.96 \mathrm{f}$ & $3.19 \mathrm{~g}$ & $2.79 \mathrm{C}$ & $2.00 \mathrm{c}$ & $2.26 \mathrm{e}$ & $2.54 \mathrm{f}$ & $2.70 \mathrm{~g}$ & $2.38 \mathrm{C}$ \\
\hline Mean & $2.14 \mathrm{~A}$ & $2.36 \mathrm{~B}$ & $2.60 \mathrm{C}$ & $2.84 \mathrm{D}$ & & $1.81 \mathrm{~A}$ & $2.09 \mathrm{~B}$ & $2.28 \mathrm{C}$ & $2.42 \mathrm{D}$ & \\
\hline
\end{tabular}

Table (7): Effect of complete fertilizer (Kristalon) and salicylic acid concentrations on total chlorophylls content (mg/g, FW) and total carbohydrate percentage of German chamomile (Matricaria chamomilla L.) plant during both seasons.

\begin{tabular}{|c|c|c|c|c|c|c|c|c|c|c|}
\hline \multirow{4}{*}{$\begin{array}{l}\text { Kristalon } \\
\text { Conc. (g/l) }\end{array}$} & \multicolumn{10}{|c|}{ Salicylic acid conc. (ppm) } \\
\hline & 0.0 & 25 & 50 & 100 & Mean & 0.0 & 25 & $\mathbf{5 0}$ & 100 & Mean \\
\hline & \multicolumn{5}{|c|}{ First season } & \multicolumn{5}{|c|}{ Second season } \\
\hline & \multicolumn{10}{|c|}{ Total chlorophylls content $(\mathrm{mg} / \mathrm{g}, \mathrm{FW})$} \\
\hline $\mathbf{0 . 0}$ & $2.61 \mathrm{a}$ & $2.81 \mathrm{~b}$ & $3.53 \mathrm{c}$ & $4.00 \mathrm{~d}$ & $3.24 \mathrm{~A}$ & $2.75 \mathrm{a}$ & $3.00 \mathrm{~b}$ & $3.75 \mathrm{~cd}$ & $4.10 \mathrm{e}$ & $3.40 \mathrm{~A}$ \\
\hline 2.0 & $2.96 \mathrm{~b}$ & $3.55 \mathrm{c}$ & $4.13 \mathrm{~d}$ & $4.63 \mathrm{e}$ & $3.82 \mathrm{~B}$ & $3.11 \mathrm{~b}$ & $3.82 \mathrm{~d}$ & $4.32 \mathrm{e}$ & $4.91 \mathrm{f}$ & $4.04 \mathrm{~B}$ \\
\hline 4.0 & $3.35 \mathrm{c}$ & $3.97 \mathrm{~d}$ & $4.52 \mathrm{e}$ & $4.96 \mathrm{f}$ & $4.20 \mathrm{C}$ & $3.55 \mathrm{c}$ & $4.14 \mathrm{e}$ & $4.72 \mathrm{f}$ & $5.21 \mathrm{~g}$ & $4.40 \mathrm{C}$ \\
\hline \multirow[t]{2}{*}{ Mean } & $2.97 \mathrm{~A}$ & $3.44 \mathrm{~B}$ & $4.06 \mathrm{C}$ & $4.53 \mathrm{D}$ & & $3.13 \mathrm{~A}$ & $3.65 \mathrm{~B}$ & $4.26 \mathrm{C}$ & $4.74 \mathrm{D}$ & \\
\hline & \multicolumn{10}{|c|}{ Total carbohydrate percentage } \\
\hline $\mathbf{0 . 0}$ & $13.24 \mathrm{a}$ & $13.51 \mathrm{~b}$ & $13.66 \mathrm{bc}$ & $13.90 \mathrm{c}$ & $13.58 \mathrm{~A}$ & $13.41 \mathrm{a}$ & $14.11 \mathrm{c}$ & $14.68 \mathrm{de}$ & $15.01 \mathrm{ef}$ & $14.30 \mathrm{~A}$ \\
\hline 2.0 & $13.63 \mathrm{bc}$ & $13.85 \mathrm{bc}$ & $14.11 \mathrm{~cd}$ & $14.30 \mathrm{~d}$ & $13.97 \mathrm{~B}$ & $13.81 \mathrm{~b}$ & $14.25 \mathrm{~cd}$ & $14.63 \mathrm{de}$ & $14.91 \mathrm{e}$ & $14.40 \mathrm{~A}$ \\
\hline 4.0 & $13.85 \mathrm{bc}$ & $14.11 \mathrm{~cd}$ & $14.35 \mathrm{~d}$ & $14.64 \mathrm{~d}$ & $14.23 \mathrm{C}$ & $14.11 \mathrm{c}$ & $14.46 \mathrm{~d}$ & $14.75 \mathrm{e}$ & $15.25 \mathrm{f}$ & $14.64 \mathrm{~B}$ \\
\hline Mean & $13.57 \mathrm{~A}$ & $13.82 \mathrm{~B}$ & $14.04 \mathrm{C}$ & $14.28 \mathrm{D}$ & & $13.78 \mathrm{~A}$ & $14.27 \mathrm{~B}$ & $14.68 \mathrm{C}$ & $15.05 \mathrm{D}$ & \\
\hline
\end{tabular}


Table (8): Effect of complete fertilizer (Kristalon) and salicylic acid concentrations on nitrogen and crude protein percentages of German chamomile (Matricaria chamomilla $\mathbf{L}$.) plant during both seasons.

\begin{tabular}{|c|c|c|c|c|c|c|c|c|c|c|}
\hline \multirow{4}{*}{$\begin{array}{l}\text { Kristalon } \\
\text { Conc. (g/l) } \\
\end{array}$} & \multicolumn{10}{|c|}{ Salicylic acid conc. (ppm) } \\
\hline & 0.0 & 25 & $\mathbf{5 0}$ & 100 & Mean & 0.0 & 25 & 50 & 100 & Mean \\
\hline & \multicolumn{5}{|c|}{ First season } & \multicolumn{5}{|c|}{ Second season } \\
\hline & \multicolumn{10}{|c|}{ Nitrogen percentage } \\
\hline $\mathbf{0 . 0}$ & $2.05 \mathrm{a}$ & $2.35 \mathrm{bc}$ & $2.46 \mathrm{c}$ & $2.60 \mathrm{~d}$ & $2.36 \mathrm{~A}$ & $2.03 \mathrm{a}$ & $2.26 \mathrm{~b}$ & $2.42 \mathrm{~d}$ & $2.47 \mathrm{~d}$ & $2.29 \mathrm{~A}$ \\
\hline 2.0 & $2.09 \mathrm{a}$ & $2.44 \mathrm{c}$ & $2.63 \mathrm{~d}$ & $2.75 \mathrm{e}$ & $2.48 \mathrm{~B}$ & $2.25 \mathrm{~b}$ & $2.35 \mathrm{c}$ & $2.47 \mathrm{~d}$ & $2.63 \mathrm{f}$ & $2.42 \mathrm{~B}$ \\
\hline 4.0 & $2.28 \mathrm{~b}$ & $2.46 \mathrm{c}$ & $2.81 \mathrm{ef}$ & $2.90 \mathrm{f}$ & $2.61 \mathrm{C}$ & $2.32 \mathrm{c}$ & $2.55 \mathrm{e}$ & $2.60 \mathrm{ef}$ & $2.69 \mathrm{f}$ & $2.54 \mathrm{C}$ \\
\hline \multirow[t]{2}{*}{ Mean } & $2.14 \mathrm{~A}$ & $2.42 \mathrm{~B}$ & $2.63 \mathrm{C}$ & $2.75 \mathrm{D}$ & & $2.20 \mathrm{~A}$ & $2.38 \mathrm{~B}$ & $2.50 \mathrm{C}$ & $2.60 \mathrm{D}$ & \\
\hline & \multicolumn{10}{|c|}{ Crude protein percentage } \\
\hline $\mathbf{0 . 0}$ & $12.81 \mathrm{a}$ & $14.68 \mathrm{bc}$ & $15.41 \mathrm{c}$ & $16.25 \mathrm{~d}$ & $14.79 \mathrm{~A}$ & $12.70 \mathrm{a}$ & $14.12 \mathrm{~b}$ & $15.13 \mathrm{~d}$ & $15.44 \mathrm{e}$ & $14.35 \mathrm{~A}$ \\
\hline 2.0 & $13.10 \mathrm{a}$ & $15.27 \mathrm{c}$ & $16.45 \mathrm{~d}$ & $17.18 \mathrm{e}$ & $15.50 \mathrm{~B}$ & $14.06 \mathrm{~b}$ & $14.72 \mathrm{c}$ & $15.44 \mathrm{e}$ & $16.43 \mathrm{~g}$ & $15.16 \mathrm{~B}$ \\
\hline 4.0 & $14.27 \mathrm{~b}$ & $15.41 \mathrm{c}$ & $17.56 \mathrm{ef}$ & $18.16 \mathrm{f}$ & $16.35 \mathrm{C}$ & $14.52 \mathrm{c}$ & $15.93 \mathrm{f}$ & $16.25 \mathrm{~g}$ & $16.81 \mathrm{~h}$ & $15.88 \mathrm{C}$ \\
\hline Mean & $13.39 \mathrm{~A}$ & $15.12 \mathrm{~B}$ & $16.47 \mathrm{C}$ & $17.20 \mathrm{D}$ & & $13.76 \mathrm{~A}$ & $14.92 \mathrm{~B}$ & $15.61 \mathrm{C}$ & $16.23 \mathrm{D}$ & \\
\hline
\end{tabular}

Table (9): Effect of complete fertilizer (Kristalon) and salicylic acid concentrations on phosphorus and potassium percentages of German chamomile (Matricaria chamomilla $\mathbf{L}$.) plant during both seasons.

\begin{tabular}{|c|c|c|c|c|c|c|c|c|c|c|}
\hline \multirow{2}{*}{$\begin{array}{l}\text { Kristalon } \\
\text { Conc. (g/l) }\end{array}$} & \multicolumn{10}{|c|}{ Salicylic acid conc. (ppm) } \\
\hline & 0.0 & 25 & 50 & 100 & Mean & 0.0 & 25 & 50 & 100 & Mean \\
\hline & \multicolumn{6}{|c|}{ First season } & \multicolumn{4}{|c|}{ Second season } \\
\hline & \multicolumn{10}{|c|}{ Phosphorus percentage } \\
\hline $\mathbf{0 . 0}$ & $0.433 \mathrm{a}$ & 0.467 ef & $0.523 \mathrm{~d}$ & $0.583 \mathrm{f}$ & $0.502 \mathrm{~A}$ & $0.407 \mathrm{a}$ & $0.450 \mathrm{~b}$ & $0.540 \mathrm{e}$ & $0.610 \mathrm{~g}$ & $0.502 \mathrm{~A}$ \\
\hline 2.0 & $0.460 \mathrm{~b}$ & $0.537 \mathrm{e}$ & $0.640 \mathrm{~g}$ & $0.650 \mathrm{~g}$ & $0.572 \mathrm{~B}$ & $0.470 \mathrm{c}$ & $0.540 \mathrm{e}$ & $0.617 \mathrm{~g}$ & $0.620 \mathrm{~g}$ & $0.562 \mathrm{~B}$ \\
\hline 4.0 & $0.490 \mathrm{c}$ & 0.567 ef & $0.680 \mathrm{~h}$ & $0.713 \mathrm{i}$ & $0.613 \mathrm{C}$ & $0.510 \mathrm{~d}$ & $0.590 \mathrm{f}$ & $0.650 \mathrm{~h}$ & $0.683 \mathrm{i}$ & $0.608 \mathrm{C}$ \\
\hline \multirow[t]{2}{*}{ Mean } & $0.461 \mathrm{~A}$ & $0.523 \mathrm{~B}$ & $0.614 \mathrm{C}$ & $0.649 \mathrm{D}$ & & $0.462 \mathrm{~A}$ & $0.527 \mathrm{~B}$ & $0.602 \mathrm{C}$ & $0.638 \mathrm{D}$ & \\
\hline & \multicolumn{10}{|c|}{ Potassium percentage } \\
\hline 0.0 & $1.83 \mathrm{a}$ & $2.07 \mathrm{c}$ & $2.15 \mathrm{~d}$ & $2.23 \mathrm{e}$ & $2.07 \mathrm{~A}$ & $1.84 \mathrm{a}$ & $2.05 \mathrm{~d}$ & $1.99 \mathrm{c}$ & $2.14 \mathrm{ef}$ & $2.00 \mathrm{~A}$ \\
\hline 2.0 & $1.88 \mathrm{a}$ & $1.97 \mathrm{bc}$ & $2.17 \mathrm{de}$ & $2.27 \mathrm{e}$ & $2.07 \mathrm{~A}$ & $1.93 \mathrm{~b}$ & $2.12 \mathrm{e}$ & $2.25 \mathrm{~g}$ & $2.30 \mathrm{~g}$ & $2.15 \mathrm{~B}$ \\
\hline 4.0 & $1.94 \mathrm{~b}$ & $2.02 \mathrm{c}$ & $2.29 \mathrm{e}$ & $2.40 \mathrm{f}$ & $2.16 \mathrm{~B}$ & $2.00 \mathrm{c}$ & $2.18 \mathrm{f}$ & $2.36 \mathrm{~h}$ & $2.42 \mathrm{i}$ & $2.24 \mathrm{C}$ \\
\hline Mean & $1.88 \mathrm{~A}$ & $2.02 \mathrm{~B}$ & $2.21 \mathrm{C}$ & $2.30 \mathrm{D}$ & & $1.92 \mathrm{~A}$ & $2.12 \mathrm{~B}$ & $2.20 \mathrm{C}$ & $2.29 \mathrm{D}$ & \\
\hline
\end{tabular}


improving the level of mineral nutrient utilization and, in consequence, plant nutritional status and and fitness (Elmer et al., 2007). It could be proved that foliar absorption of mineral nutrients is from 8 to 20 times more efficient than soil application. Nevertheless, such high efficiency is not commonly achieved in agricultural practice (Kuepper, 2003).

The above mentioned results proved the enhancing effect of treating plants with SA on assessed chemical constituents. Many workers have also reported the stimulatory effect of SA on plant nutrients content (Kord and Hathout, 1992; Sarangthem and Singh, 2003 and Gharib, 2006), carbohydrate percentage (Gharib, 2006 and Elwan and El-Hamahmy, 2009) and chlorophyll content (Khurana and Makeshwari, 1978 and Gharib, 2006). Application of SA might improve physiological performance in terms of production of photosynthates, total oil and dry matter yield, which can be related to increased nutrient uptake by SA-treated plants (Abad-Farooq and Misra, 1983 and Cheol et al., 2001). This also may be attributed to an increase in photosynthesizing tissue, i.e., leaves (Zhou et al., 1999). Moreover, SA could play an important role in the bioproductivity of plants, that could be linked to the observed effect of promoting root length of plants (Gutierrez-Coronado et al., 1998 and Sandoval-Yepiz, 2004), where both studies indicated that the application of SA to the shoots of soybean and Tagetes erecta plants affected significantly the size of the root.

\section{REFERENCES}

Abad-Farooq A.H. and Misra A. (1983). Effect of micronutrient on oil content and plant growth in Mentha arvensis $\mathrm{L}$ var. piperascens Mal. Indian J. Plant Physiol., 2: 230-233.

Anonymous (1996). European Pharmacopoeia (3rd Ed.). Strasbourg, France: Council of Europe, pp. 121-122.

Arif M., Chohan M.A., Ali S., Gul R. and Khan S. (2006). Response of wheat to foliar application of nutrients. J. Agric. and Biol. Sci. 1 (4): 30-34.

Aziz E. (2004). Stimulatory effect of spraying marigold plants (Calendula officinalis L.) with potassium, magnesium and copper sulphate. Egypt. J. Appl. Sci. 19:240-262.

Baloch Q.B., Chachar Q.I. and Tareen M.N. (2008). Effect of foliar application of macro and micro nutrients on production of green chilies (Capsicum annuum L.). J. Agric.
Tech. 4(2):177-184

Bernal M., Cases R., Picorel R. and Yruela I. (2007). Foliar and root $\mathrm{Cu}$ supply affect differently $\mathrm{Fe}$ and Zn-uptake and photosynthetic activity in soybean plants. Environ. Exp. Botany 60: 145-150.

Brown J.D. and Lilleland O. (1964). Rapid determination of potassium and sodium in plant material and soil extracts by flame photometry. Proc. Amer. Soc. Hort. Sci., 48: 341-346.

Chen Z., Ricigliano J.R. and Klessig D.F. (1993). Purification and characterization of soluble salicylic acid binding protein from tobacco. Proc. Natl. Acad. Sci. USA 90: 9533-9537.

Cheol W.N., Lee M.J., Park K.W., Maloupa E. and Gerasopoulos D. (2001). Effects of magnesium ion content in nutrient solution on the growth and quality of marjoram. Acta-Hort. 548: 485-490.

Conrath U., Chen Z., Ricigliano J.R. and Klessig D.F. (1995). Two inducers of plant defense responses, 2, 6-dichloroisonicotinic acid and salicylic acid, inhibit catalase activity in tobacco. Proc. Natl. Acad. Sci. USA 92: 7143-7147.

Elmer P.A.G., Spiersa T.M. and Wood P.N. (2007). Effects of pre-harvest foliar calcium sprays on fruit calcium levels and brown rot of peaches. Crop Prot. 26(1):11-18.

El-Sherbeny S.E., Khalil M.Y., Hussein M.S. and Aly M.S. (2008). Effect of sowing date and application of foliar fertilizers on the yield and chemical composition of rue (Ruta graveolens L.) herb. Herba polonica 54 (1): 47-56.

Elwan M.W.M. and El-Hamahmy M.A.M. (2009). Improved productivity and quality associated with salicylic acid application in greenhouse pepper. Scientia Horticulturae 122: 521-526.

Gharib F.A. (2006). Effect of salicylic acid on the growth, metabolic activities and oil content of basil and marjoram. Int. J. Agri. Biol. 84:485492.

Gomez K.A. and Gomez A.A. (1984). Statistical Procedures for Agricultural Research. Wiley, New York, USA.

Gross J. (1991). Pigments in Vegetables: Chlorophylls and Carotenoids. Van Nostrand Reinhold, New York, USA.

Gunes A., Inal A., Alpaslan M., Eraslan F., Guneri-Bagci E. and Cicek N. (2007). Salicylic acid induced changes on some physiological parameters symptomatic for 
oxidative stress and mineral nutrition in maize (Zea mays L.) grown under salinity. J. Plant Physiol. 164:728-736.

Gutierrez-Coronado M., Trejo C.L. and LarqueSaavedra A. (1998). Effects of salicylic acid on the growth of roots and shoots in soybean. Plant Physiol. Biochem. 36: 563565.

Hara M., Furukawa J., Sato A., Mizoguchi T. and Miura K. (2011). A biotic stress and role of salicylic acid in plants. In A biotic Stress Responses in Plants: Metabolism, Productivity and Sustainability (Ahmad, P. and Prasad, M.N.V., Eds). New York: Springer, pp. 235-251.

Herbert D., Philipps P. J. and Strange R.E. (1971). Carbohydrate analysis. Methods Enzymol. 5B: 265-277.

Hucker T. W. G. and Catroux G. (1980). Phosphorus in sewage ridge and animal waster slurries. Proceeding of the EEC Seminar, Haren (Gr); Groningen Netherlands, 12, 13 June.

Kandeel A.M. (2002). Effect of foliar application with some micro-nutrients on the vegetative growth, volatile oil yield and chemical composition of Ocimum basilicum L. plant. Annals Agric. Sci., Ain Shams Univ., Cairo 47: 373-387.

Khalil M.Y., Hussein M.S. and El-Sherbeny S.E. (2001). A comparative study on the effect of some foliar fertilizers on the growth and yield of Sinapis alba and Nigella sativa plants. Egypt. J. Hort. 28:371-385.

Khare C.P. (2007). Indian Medicinal Plants. Springer Science Business Media, LLC. New York, USA.

Khurana J.P. and Makeshwari S.C. (1978). Induction of flowering in Lemna paucicostata by salicylic acid. Plant Sci. Lett. 12: 127-32.

Kord M. and Hathout, T. (1992). Changes in some growth criteria, metabolic activities and endogenous hormones in tomato plants consequent to spraying with different concentrations of salicylaldehyde. Egypt. J. Physiol. Sci. 16: 117-139.

Kováčik J., Grúz J., Bačkor M. Strnad M. and Repčák M. (2009). Salicylic acid induced changes to growth and phenolic metabolism in Matricaria chamomilla plants. Plant Cell Rep. 28:135-143.

Kuepper G. (2003). Foliar fertilization. ATTRA. https://attra.ncat.org/attrapub/summaries/summary.php?pub=286.
Mendoza A.B., Godina F.R., Torres V.R. Rodriguez H.R. and Maiti R.K. (2002). Chilli seed treatment with salicylic and sulfosalicylic acid modifies seedling epidermal anatomy and cold stress tolerance. Crop Res. 24: 19-25.

Metwally A., Finkemeier I. Georgi M. and Dietz K.J. (2003). Salicylic acid alleviates the cadmium toxicity in barley seedlings. Plant Physiol. 132: 272-281.

Naguib M. I. (1969). Colorimeter determination of nitrogen components of plant tissues. Bull. Fac. Sci., Cairo Univ. 43 : 1-9.

Naguib N.Y., Khalil M.Y. and El-Sherbeny S.E. (2005). Response of Ruta graveolens L. to sowing dates and foliar micronutrients. J. App. Sci. Res. 1(2): 176-189.

Pastírová A., Repčák M. and Eliašová A. (2004). Salicylic acid induces changes of coumarin metabolites in Matricaria chamomilla L. Plant Science 167: 819-824.

Salamon I. (2007). Effect of the internal and external factors on yield and qualitativequantitative characteristics of chamomile essential oil. In: Proceedings of the First International Symposium on Chamomile Research, Development and Production, Presov, Slovakia, pp. 45-64.

Sandoval-Yepiz M.R. (2004). Reguladores de crecimiento XXIII: Efecto del acido salicýlico en la biomasa del cempazuchitl (Tagetes erecta). In: Tesis de Licenciatura, Instituto Tecnologico Agropecuario, Conkal, Yucatan, Mexico.

Sarangthem K. and Singh T.H.N. (2003). Efficacy of salicylic acid on growth, nitrogen metabolism and flowering of Phaseolus vulgaris. Crop Res., 26: 355-360.

Shakirova F.E., Sakhabutdinova A.R., Bezrukova M.V., Fatkhutdinova R.A. and Fatkhutdinova D.R. (2003). Changes in the hormonal status of wheat seedlings induced by salicylic acid and salinity. Plant Sci. 164:317-322.

Stevens J., Senaratna T. and Sivasithamparam K. (2006). Salicylic acid induces salinity tolerance in tomato (Lycopersicon esculentum cv. Roma): associated changes in gas exchange, water relations and membrane stabilisation. Plant Growth Regul. 49:77-83.

Szepesi A., Poor P., Gemes K., Horvath E. and Tari I. (2008). Influence of exogenous salicylic acid on antioxidant enzyme activities in the roots of salt stressed tomato 
plants. Acta Biol. 52:199-200.

Taguchi G., Yazawa T., Hayashida N. and Okazaki M. (2001). Molecular cloning and heterologous expression of novel glucosyltransferases from tobacco cultured cells that have broad substrate specificity and are induced by salicylic acid and auxin. Eur. J. Biochem. 268:4086- 4094.

Taha R.A. (2012). Effect of some soil types and some commercial foliar fertilizers on growth, flowering, bulb productivity and chemical composition of iris plants. J. Hort.
Sci. \& Ornamental Plants 4 (2): 221-226.

Vicente M.R. and Plasencia J. (2011). Salicylic acid beyond defence: its role in plant growth and development. J. Exp. Bot. 62 (10): 3321-3338.

Zhou X.M., Mackeuzie A.F., Madramootoo C.A. and Smith D.L. (1999). Effect of some injected plant growth regulators, with or without sucrose, on grain production, biomass and photosynthetic activity of field-grown corn plants. J. Agron. Crop Sci. 183: 103-110.

$$
\begin{aligned}
& \text { تحسين إنتاجية البابونج الألماني بالرش الورقي }
\end{aligned}
$$

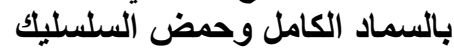

$$
\begin{aligned}
& \text { هشام عبد العال الثامي ـ أحمد شاكر حسين جندي } \\
& \text { قسم البساتين - كلية الزر اعة - جامعة الزقازيق }
\end{aligned}
$$

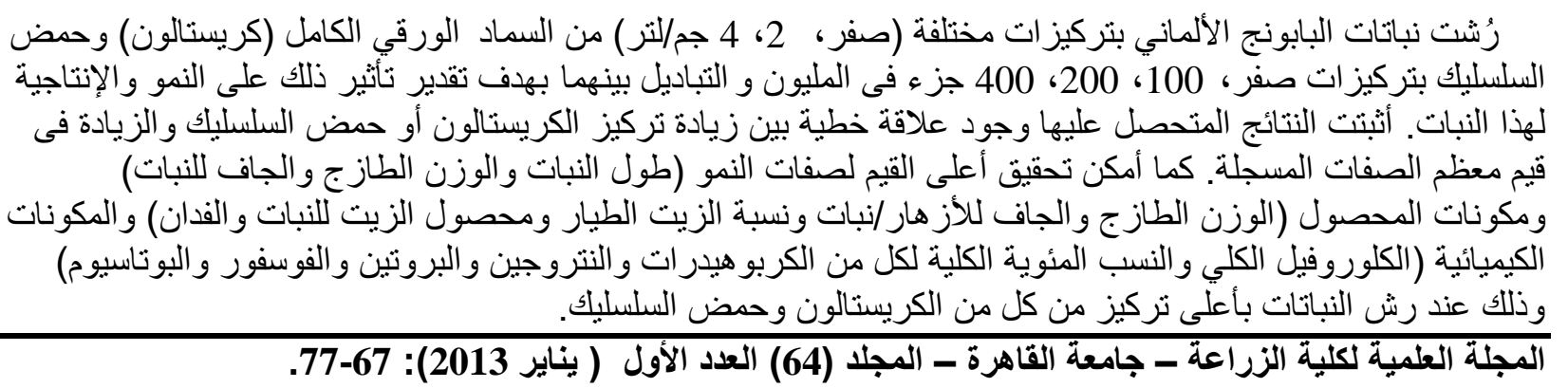

